\title{
USAHA GURU PENDIDIKAN AGAMA ISLAM MENGEMBANGKAN POTENSI EMOSIONAL SISWA DALAM MENINGKATKAN PROSES PEMBELAJARAN (STUDI DI SMP N 29 PADANG)
}

\author{
Silvia Susrizal \\ Program studi Manajemen Pendidikan, Fakultas Tarbiyah dan Ilmu Keguruan, \\ IAIN Batusangkar \\ Korespondensi: Kompleks TPI Rambatan, Batusangkar, Sumatera Barat \\ e-mail: susriza lsilvia @ya hoo.co.id
}

\begin{abstract}
This study was conducted because of the need for the development of the emotional potential in the learning process conducted by teachers of Islamic Education at SMP N 29 Padang. The purpose of this study is to determine the efforts undertaken by teachers of Islamic Religious Education develop the emotional potential of students in improving the learning process. The research method used is field research is descriptive. In this research has not seen efforts of Islamic religious teachers in developing the emotional potential of their students, including indication is that students have not yet felt a really enjoyable learning atmosphere such as learning PAIKEM, but instead students feel the lack of learning atmosphere, full of uneasiness, Not well developed and maximal.
\end{abstract}

Keywords: usaha guru pendidikan agama Islam, potensi, emosional, proses pembelajaran

\section{PENDAHULUAN}

Manusia dilahirkan ke atas dunia ini telah dibekali dengan potensi yang akan membuatnya hidup, bahagia dan berhasil. Manusia dengan konsep diri menjadi unsur terpenting dalam menentukan pengembangan diri. Karena pada dasarnya semua manusia mempunyai kesamaan potensi, akan tetapi potensi itu ada yang digali dan ditumbuh suburkan menjadi potensi yang luar biasa, di sisi lain ada yang tidak mengembangkan potensinya dengan maksimal, karena potensi-potensi akan berkembang sesuai dengan faktor-faktor yang mendukungnya.
Dalam al-Qur'an potensi yang dimiliki manusia diistilahkan dengan fitrah. Potensi atau fitrah yang dimiliki manusia pada hakikatnya merupakan kemampuan dasar manusia yang meliputi kemampuan mempertahankan kelestarian kehidupannya, kemampuan rasional maupun kemampuan spiritual (Samsul Nizar, 2001: 209). Dalam surat Ar-rum ayat 30 Allah menjelaskan:

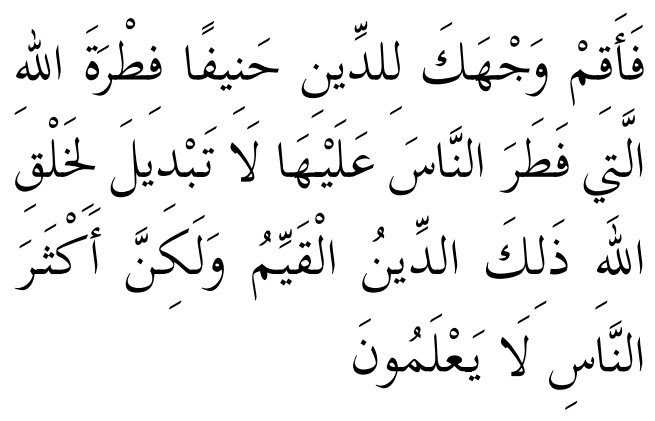


Maka hadapkanlah wajahmu dengan lurus kepada agama (Allah); (tetaplah atas) fitrah Allah yang telah menciptakan manusia menurut fitrah itu. Tidak ada perubahan pada fitrah Allah. (Itulah) agama yang lurus; tetapi kebanyakan manusia tidak mengetahui.

Begitu juga menurut hadits yang diriwayatkan oleh Imam Bukhari, sebagai berikut:
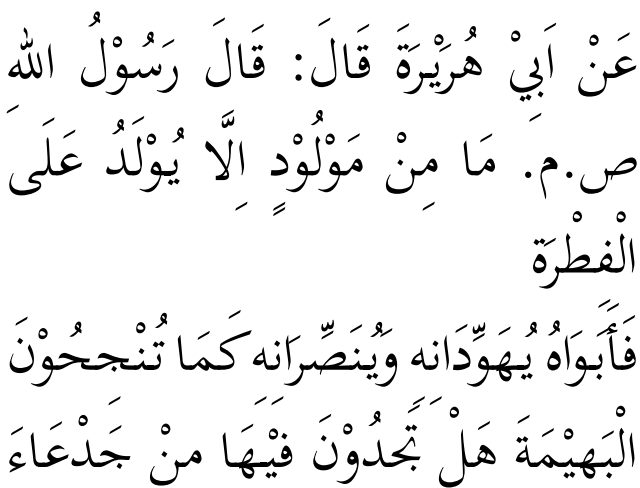

r -

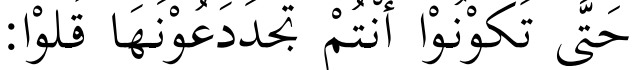

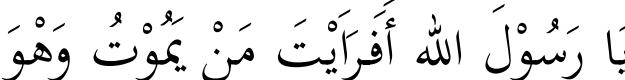

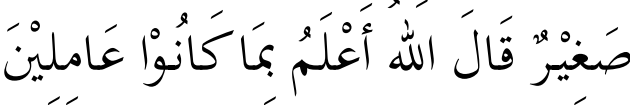

Dari Abu Hurairah r.a Katanya: Rasulullah saw bersabda: "Setiap anak dilahirkan menurut fitrah (ciptaan asli). Kedua ibu bapanya yang menyebabkan anak itu beragama Yabudi dan Nasrani. Sebagaimana binatang ternak dilahirkan, adakah kamu dapati yang telah dipotong (dilobangi) bidungnya sehingga kamu tidak perlu lagi memotongnya?". Mereka bertanya lagi:"Ya Rasulullah! bagaimana pendapat engkau tentang anak yang meninggal di waktu kecil ?"Jawab Nabi: "Allah lebih mengetahui apa yang mereka kerjakan."

Potensi dasar ini akan menjadikan manusia makhluk yang berbeda dengan makhluk lainnya, mampu menjadi khalifah Fil Ardh, hamba yang taat, menjadi manusia inovatif, kreatif, konstruktif, dan menjadi manusia yang paripurna (Insan Kamil).

Di antara potensi dasar itu adalah potensi emosional. Potensi emosi ini sangat penting untuk manusia karena akan mengajarkan kita tentang arti integritas, kejujuran, komitmen, visi, kreatifitas, ketahanan mental, kebijaksanaan, keadilan, prinsip kepercayaan, penguasaan diri/sinergi (Ary Ginanjar Agustian, 2001: xliii).

Potensi ini sebenarnya sudah tergambar dalam pendapat ulama abad pertengahan yaitu Ibnu Taimiyah, sebagaima disitir Samsul Nizar-pada diri manusia juga memiliki di antaranya Daya ofensif (Quwwat Al Syahwat) yaitu potensi dasar yang dimiliki manusia yang mampu menginduksi objekobjek yang menyenangkan dan bermanfaat bagi kehidupannya, baik secara jasmaniah maupun rohaniah secara serasi dan seimbang.

Potensi yang diberikan Allah ini seperti yang telah dijelaskan sebelumnya akan menjadi potensi luar biasa jika dikembangkan, karena itu upaya efektif untuk maksud di atas adalah melalui upaya pendidikan, maka pelaku pendidikan mengarah dan menyatu menuju usaha pengembangan ini, di antaranya adalah guru. Dalam Pendidikan Islam guru bertanggung jawab mengantarkan manusia ke arah terciptanya Insan Kamil. 
Justru itu keberadaan pendidik dalam dunia pendidikan sangat krusial, sebab kewajibannya tak hanya mentransformasikan pengetahuan tetapi juga dituntut menginternalisasikan nilai-nilai pada peserta didik (Ramayulis, 2002: 55) melalui metode, media, materi, alat, dan kurikulum yang dirancang oleh pendidik diusahakan agar menyentuh ranah emosional peserta didik.

Sekolah Menengah Pertama Negeri (SMPN) 29 Padang sebagai salah satu lembaga pendidikan yang merupakan wadah melahirkan generasi-generasi berkualitas juga berupaya untuk mengembangkan potensi emosional siswa baik dalam proses pembelajaran di kelas maupun kegiatan non pembelajaran dengan baik sesuai dengan ilmu didaktik dan hakikat pengembangan potensi itu sendiri. Sebenarnya ada hubungan timbal balik antara usaha guru pendidikan Agama Islam dalam pengembangan potensi dengan proses pembelajaran. Jika usaha pengembangan potensi maksimal maka akan berdampak positif terhadap proses pembelajaran, dan begitu juga sebaliknya jika pelaksanaan proses pembelajaran yang terjadi efektif maka potensi akan bisa dikembangkan dengan baik.

\section{KAJIAN TEORITIS}

\section{Potensi Emosional}

\section{a. Pengertian Potensi Emosional}

Para pakar memberikan defenisi beragam pada potensi emosional, diantaranya adalah (Makmun Mubayidh, 2006: 7-9) "Kemampuan untuk menyikapi pengetahuanpengetahuan emosional dalam bentuk menerima, memahami, dan mengelolanya".

Menurut defenisi ini potensi emosional mempunyai 4 dimensi berikut (Makmun Mubayidh: 2006: 7-9):

1) Mengenali, menerima, dan mengekspresikan emosi (kefasihan emosional)

2) Menyertakan emosi dalam kerja-kerja intelektual, Caranya:

3) Memahami dan menganalisa emosi

4) Mengelola emosi

Potensi emosional juga dapat diartikan sebagai kemampuan merasakan, memahami dan secara efektif menerapkan daya dan kepekaan emosi sebagai sumber energi, informasi koneksi dan pengaruh yang manusiawi, dan dapat juga dikatakan sebagai kemampuan mendengar suara hati sebagai sumber informasi-informasi.

b. Macam-Macam Potensi Emosional Manusia

Potensi emosional yang manusia miliki terbaca dari emosi-emosi yang dilahirkannya dalam tingkah laku atau gerak geriknya, seperti dalam perspektif Islam, sebagai berikut:

\section{1) Takut}

Emosi takut merupakan salah satu emosi penting dalam kehidupan manusia, karena membantu manusia dalam memeliharanya dari bahaya-bahaya yang 
mengancamnya dan dengan demikian membantunya dalam melestarikan kehidupannya. Manfaat rasa takut tidak hanya terbatas untuk menjaga manusia dari berbagai bahaya yang mengancamnya dalam kehidupan duniawi saja, tapi diantara kemanfaatannya yang terutama sekali ialah mendorong seorang mukmin untuk memelihara dirinya dari azab Allah dalam kehidupan akhirat nanti (Utsman Najati, 2005: 100) Tapi takut juga akan bisa membahayakan dirinya sendiri.

Di bawah ini beberapa bentuk emosi takut yang dialami oleh manusia, yaitu:

a) Takut kepada siksaan Allah, akan mendorong orang-orang mukmin agar tidak terjerumus ke dalam kemaksiatan, berpegang pada ketaqwaan, teratur dalam beribadah kepada Allah (Utsman Najati, 2005: 100) Seperti dalam Alqur'an, di antaranya:

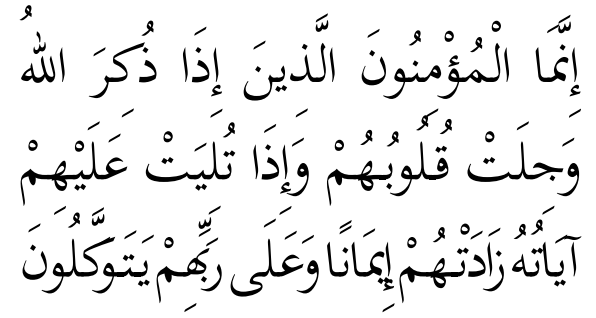

Sesungguhnya orang-orang yang beriman itu adalah mereka yang apabila disebut nama Allah gemetarlah hati mereka, dan apabila dibacakan kepada mereka ayat-ayatNya, bertambablah iman mereka (karenanya) dan kepada Rabblah mereka bertawakkal, (QS. Al-Anfal:2) b) Takut Karena Allah Takut karena Allah merupakan takut yang penting dalam kehidupan orang mukmin, takut kepada Allah dipandang sebagai salah satu pilar dalam keimanan kepadaNya dan sebagai pondasi yang penting dalam pembentukan seorang mukmin, seperti yang disinyalir Allah dalam Alqur'an surat Al-Bayyinah ayat 7-8:

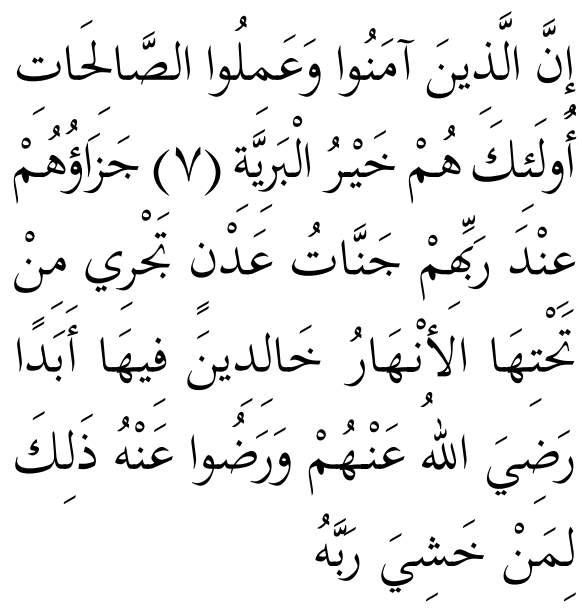

Sesungguhnya orang-orang yang beriman dan mengerjakan amal saleh mereka itu adalah sebaik-baik makbluk. Balasan mereka di sisi Rabb mereka ialah surga Adn yang mengalir di bawahnya sungai-sungai; mereka kekal di dalamnya selama-lamanya. Allah ridha terhadap mereka dan merekapun ridha kepada-Nya. Yang demikian itu adalah (balasan) bagi orang yang takut kepada Rabbnya. (QS. Al-Bayyinah:7-8)

Juga dalam Hadits Rasul yang artinya:

"Tidak seorangpun yang meninggal dunia, melainkan ia akan menyesal. Para sahabat bertanya, "apa yang membuat seseorang, menyesal ya 
Rasulullah saw?" Rasulullah saw menjawab," jika ia seorang baik, ia menyesal mengapa tidak menambah kebaikannya. Jika ia seorang buruk, ia menyesal mengapa tidak meninggalkan perbuatan buruknya". (HR. Tarmidzi)

c) Takut Mati

Takut mati banyak terjadi di kalangan orang-orang. Keimanan yang benar kepada Allah swt akan menghilangkan perasaan takut mati. Takut mati akan terjadi sangat hebat pada orang-orang durhaka yang takut ditimpa kematian sebelum bertobat. Dengan demikian, takut mati pada hakikatnya hanyalah kembali pada terhalangnya taubat. Dalam kaitan itu, takut mati mempunyai korelasi yang erat dengan takut kepada Allah swt (Utsman Najati, 2005: 111), sesuai dengan firman Allah:

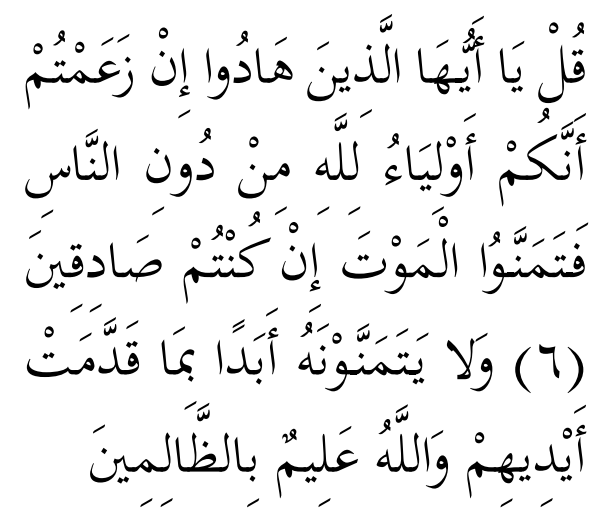

Katakanlah: Hai orang-orang yang menganut agama Yahudi, jika kamu mendakwakan bahwa sesungguhnya kamu sajalah kekasih Allah bukan manusia-manusia yang lain, maka harapkanlah kematianmu, jika kamu adalah orang-orangyang benar. Mereka tiada akan mengharapkan kematian itu selama-lamanya disebabkan kejahatan yang telah mereka perbuat dengan tangan mereka sendiri. Dan Allah Maha Mengetahui akan orang-orang yang zalim. (QS. Al-jumu'ah: 6-7)

d) Takut Miskin

Termasuk takut yang banyak menimpa manusia. Termasuk iman kepada Allah adalah menghilangkan perasaan takut miskin. Seorang mukmin yang benar dalam keimanannya akan tahu persis bahwa rezeki yang ada di tangan Allah swt. Oleh karena itu, tidak ada alasan untuk takut miskin, seperti dalam QS. Adz-Dzariyat: 58

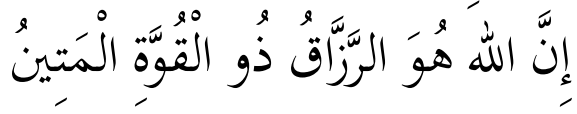
Sesungguhnya Allah Dialah Maha Pemberi rezki Yang Mempunyai Kekuatan lagi Sangat Kokoh. (QS. Adz-dzariyat:58)

e) Takut Kepada Orang Lain Merupakan takut yang terjadi di kalangan banyak orang yang merasa takut dianiaya oleh orang kuat, orangorang yang memiliki pengaruh dan kekuasaan, serta orang-orang yang zalim dan kejam.

\section{2) Marah}

Marah merupakan emosi penting yang akan melaksanakan fungsi penting bagi manusia. Marah akan membantu manusia dalam menjaga dirinya. alQur'an memuji penggunaan kekerasan 
terhadap kaum kafir yang menghalangi penyebaran Islam. Kekerasan di sini timbul karena marah di jalan Allah dan dalam rangka menyebarluaskan da’wah Islam. Allah swt berfirman dalam menggambarkan Rasulullah saw dan orang-orang mukmin yang ada padanya dalam QS. Surat Al-Fath ayat 29.

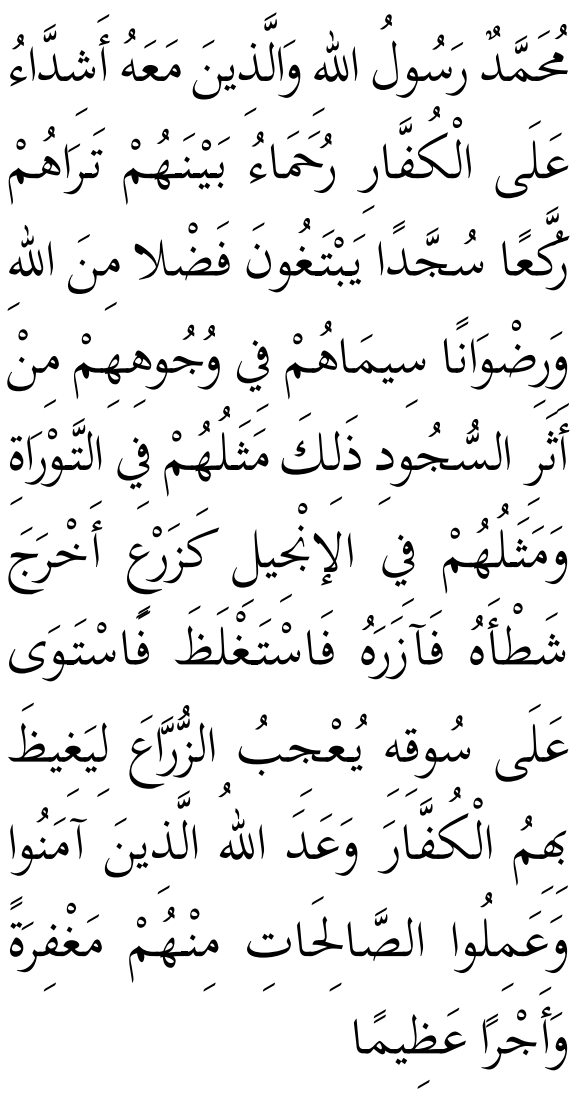

Muhammad itu adalah utusan Allah dan orang-orang yang bersama dengan Dia adalah keras terhadap orang-orang kafir, tetapi berkasih sayang sesama mereka. kamu Lihat mereka ruku' dan sujud mencari karunia Allah dan keridhaan-Nya, tanda-tanda mereka tampak pada muka mereka dari bekas sujud. Demikianlah sifat-sifat mereka dalam Taurat dan sifat-sifat mereka dalam Injil, Yaitu seperti tanaman yang mengeluarkan tunasnya Maka tunas itu menjadikan tanaman itu kuat lalu menjadi besarlah Dia dan tegak Lurus di atas pokoknya; tanaman itu menyenangkan hati penanampenanamnya karena Allah hendak menjengkelkan hati orang-orang kafir (dengan kekuatan orang-orangmukmin). Allah menjanjikan kepada orang-orang yang beriman dan mengerjakan amal yang saleh di antara mereka ampunan dan pahala yang besar.

Di dalam al-Qur'an telah dikemukakan gambaran tentang emosi marah dan dampaknya pada perilaku manusia. Manusia cenderung merespons emosi marah dengan menghindari kendalakendala yang menghalangi pemuasaan motif untuk tujuan-tujuannya baik kendala itu bersifat pribadi, materi atau syarat-syarat sosial. Namun yang banyak terjadi adalah menyalurkan marah kepada orang lain yang sesungguhnya bukan merupakan kendala yang menghalangi tujuan-tujuan manusia kepada orang lain yang bukan merupakan sebab memicu emosi marah.

\section{3) Benci}

Benci adalah emosi yang bertolak belakang dengan emosi cinta. Benci merupakan ungkapan perasaan yang tidak memandang baik dan tidak menerima, tidak senang, dan muak serta keinginan untuk menjauhi persoalan yang dapat menimbulkan perasaan tersebut, baik orang, sesuatu, ataupun tindakan. 
Iman akan memberikan pengaruh kepada orang mukmin, di antaranya akan mendorong orang mukmin untuk menepis kebencian kepada sesuatu yang dibenci oleh Allah.

\section{4) Cemburu}

Cemburu biasanya dirasakan manusia apabila ia telah merasakan orang yang dicintainya menunjukkan perhatiannya kepada orang lain. Emosi cemburu merupakan emosi yang kompleks. Pada cemburu terdapat beberapa emosi lain, khususnya perasaan benci. Oleh karena itu, umumnya cemburu dibarengi benci, dengki, dan keinginan untuk menyakiti orang yang memicu terjadinya cemburu.

\section{5) Sedih}

Sedih emosi yang bertolak belakang dengan senang dan gembira.

\section{6) Sesal}

Sesal keadaan emosional yang timbul karena perasaan berdosa, kesedihan atas perbuatan dosa yang dilakukan, celaan pada diri sendiri atas apa yang telah dilakukan, dan angan-angan seandainya tidak melakukan itu.

\section{7) Emosi-emosi lainnya}

Al-Qur'an mengisyaratkan pula beberapa emosi lainnya yang belum diterangkan.

Kematangan emosional terjadi ketika seseorang berubah dari mencintai dirinya sendiri (egois), kepada mengutamakan orang lain (Måruf Zuraiq, 2008: 248).
Konsep kecerdasan emosional terkait dengan sikap-sikap terpuji dari qalbu dan akal yakni sikap bersahabat, kasih sayang, empati, takut berbuat salah, keimanan, dorongan moral, bekerja sama, beradaptasi, berkomunikasi dan penuh perhatian serta kepedulian terhadap sesama makhluk ciptaan Tuhan. Adapun ciri yang memandai kecerdasan emosional dalam pendidikan Islam terdapat pada pendidikan akhlak. Para pakar pendidikan Islam dengan berbagai ungkapan, pada umumnya sepakat bahwa tujuan pendidikan Islam adalah membina pribadi muslim yang sempurna dan taat dalam beribadah. Termasuk salah satunya adalah akhlak mulia. Al-Akblak al karimah dalam Islam adalah hal yang berhubungan dengan kecakapan emosi dan spiritual seperti konsistensi (istiqamah), rendah hati (tawadu), usaha keras (tawakkal), ketulusan (ikhlas), totalitas (kaffah), keseimbangan (tawazun), integritas dan penyempurnaan (ihsan). Kecerdasan emosional dalam Islam disebut kognitif Qalbiyah karena hati merupakan pendidikan akhlak, sebagaimana uraian pada bab sebelumnya olehnya itu hati harus dididik, diperbaiki, diluruskan, diberi perhitungan dan diberi teguran (Ishak W. Talibo: 2)

Para pakar pendidikan telah mengemukakan bahwa pendidikan Islam di samping berupaya membina kecerdasan intelektual, keterampilan dan raganya, juga membina jiwa dan hati nuraninya. Berarti secara umum pendidikan Islam membina kecerdasan intelektual (IQ), kecerdasan emosional (EQ). Di samping 
kedua kecerdasan tersebut, pendidikan Islam juga membina kecerdasan spiritual (SQ). Bahkan dalam konsep pendidikan Islam, kecerdasan spiritual adalah landasan IQ dan EQ. Kecerdasan intelektual tidak mengukur kreativitas, kapasitas emosi, nuansa spiritual, dan hubungan sosial, sedangkan kecerdasan Qalbiyah (kognitif Qalbiyah) apabila telah mendominasi jiwa manusia maka akan menimbulkan kepribadian yang tenang (Ishak W. Talibo: 3).

\section{METODE PENELITIAN}

Jenis penelitian ini adalah penelitian lapangan (Field Research) kualitatif yang bersifat deskriptif (Hadari Nawawi, 1996: 23). Dengan pendekatan ini akan dihasilkan data deskripsi baik dalam bentuk katakata tertulis, kata-kata lisan atau perilaku manusia yang diamati (Sutrisno Hadi, 1987: 136). Peristiwa atau kejadian yang dimaksud dalam penelitian ini berkaitan dengan usaha-usaha guru Pendidikan Agama Islam mengembangkan potensi emosional siswa dalam meningkatkan proses pembelajaran di SMP N 29 Padang.

Sumber data primer dalam penelitian ini adalah guru pendidikan Agama Islam Sekolah Menengah Pertama Negeri (SMP N 29) padang yang jumlah gurunya 3 orang, seperti dalam tabel berikut:

\begin{tabular}{|c|l|l|}
\hline No & \multicolumn{1}{|c|}{ Nama Guru } & \multicolumn{1}{c|}{ Kelas Mengajar } \\
\hline 1 & Mahlab Sufrah, BA & Kelas VII \\
\hline 2 & Drs. Yuliusman & Kelas VIII \\
\hline 3 & Hj. Elinur, S.Pd.I & Kelas IX \\
\hline
\end{tabular}

Sumber Data diperoleh dari Waka Kurikulum
Sumber data sekunder tersebut adalah wakil kepala bidang kurikulum SMP N 29 Padang.

Untuk memperoleh data yang akurat serta dapat dipertanggung jawabkan, maka dalam penelitian ini penulis menggunakan alat pengumpul data sesuai dengan informasi yang dibutuhkan dalam penelitian ini, yaitu observasi, wawancara, dan dokumentasi.

\section{HASIL PENELITIAN DAN PEMBAHASAN}

Idealnya Pengembangan potensi emosional dalam proses pembelajaran mendapatkan perhatian sama seperti potensi intelektual, bahkan prioritasnya lebih besar karena akan mempengaruhi pada suasana belajar dan proses pembelajaran. Kondisi ini sangat bergantung pada siswa dan guru. Melalui pemberian materi, dan interaksi siswa dengan guru, atau guru dengan siswa, atau siswa dengan siswa.

Berdasarkan hasil wawancara dan pengamatan yang penulis lakukan di lapangan, maka dapat penulis uraikan sebagai berikut ini:

1. Rasa ingin tahu yang besar. Seperti penjelasan penulis sebelumnya, guru belum mampu membuka kesempatan untuk mewujudkan rasa ingin tahu yang besar dari siswa. Di kelas VII guru sudah mengusahakan agar siswa memiliki rasa ingin tahu yang besar terhadap materi yang disampaikan guru, tetapi siswa hanya diam saja ketika guru bertanya. Kalau di kelas VIII guru belum maksimal 
dalam mengembangkan rasa ingin tahu siswa, karena guru tidak berupaya untuk mengeksplorasi rasa ingin tahu ini, contoh dengan mengguanakan media yang menarik dalam belajar. Pada materi Hasad penulis melihat guru masih sama dengan proses pembelajaran sebelumnnya, dengan meminta siswa mengisi LKS saja, sedangkan buku referensi siswa tidak ada dibawa oleh siswa sehingga ada siswa yang mengerjakan tugas dan ada siswa yang bermain-main saja, atau mengerjakan tugas mata pelajarn lain.

2. Kemampuan mengajukan pertanyaan yang berbobot. Siswa di kelas VII dan VIII sebenarnya ada yang mempunyai kemampuan untuk mengajukan pertanyaan yang berbobot dari materi pelajaran yang sedang dipelajari, tetapi kesempatan dan media untuk bertanya yang belum disediakan oleh guru. Seperti di kelas VIII.1 ada siswa yang sebenarnya ingin bertanya tentang materi yang sedang dipelajari atau materi lainnya tetapi karena guru tidak menyediakan kesempatan untuk bertanya, maka siswa tersebut tidak jadi mengajukan pertanyaan tersebut. Ada juga kasus lainnya di kelas VII, siswa yang berusaha menyampaikan pertanyaan kepada guru ditertawakan oleh siswa lainnya.

3. Kemampuan memberikan banyak gagasan dan usul terhadap suatu masalah. Dalam proses pembelajaran yang berlangsung di dalam kelas penulis belum melihat guru memberikan peluang agar siswa mempunyai kemampuan untuk mengeluarkan banyak gagasan dan usul terhadap suatu masalah. Penulis merasakan guru belum menguasai strategi pembelajaran yang PAIKEM sehingga guru kekurangan strategi untuk mengeksplorasi kemampuan ini. Guru agama masih menggunakan cara yang tidak kreatif sehingga proses pembelajarn menjadi bosan dan tidak produktif. Peristiwa ini penulis temukan di kelas VII dan kelas VIII.

4. Kemampuan menyatakan pendapat secara spontan dan tidak malu-malu. Menurut guru mereka siswa mereka belum semuanya berani untuk menyatakan pendapat secara spontan, mungkin saja karena ada perasaan tidak percaya diri yang tumbuh dalam diri siswa mereka.

5. Kemampuan mempunyai pendapat sendiri dan dapat mengungkapkannya, tidak mudah terpengaruh orang lain. Untuk usia SMP yang belum kuat pendiriannya -masih dalam mencari jati diri, suka meniru orang lain, dan mudah terpengaruh orang laindalam memberikan argumentasi sering sekali mudah dipengaruhi oleh teman, terkadang ketika satu siswa mencoba mengungkapkan pendapatnya sendiri, siswa yang lain mentertawakannya. Sikap seperti inilah yang membuat siswa malas mengeluarkan pendapatnya dalam proses pembelajaran. 
6. Kemampuan mempunyai daya imajinasi yang kuat. Dalam proses pembelajaran penulis belum melihat usaha guru dalam mengembangkan kemampuan ini. Kemampuan ini belum terlihat di kelas VII dan kelas VIII.

7. Kemampuan mengajukan pemikiran, gagasan pemecahan masalah yang berbeda dari orang lain (orisinil). Dalam proses pembelajaran di dalam kelas penulis belum melihat usaha guru pendidikan agama Islam dalam mengembangkan kemampuan ini. Kemampuan ini belum terlihat di kelas VII dan kelas VIII.

8. Kemampuan bekerja sendiri. belum terlihat dalam proses pembelajaran. Para siswa lebih senang mengandalkan kemampuan orang lain dalam menyelesaikan tugas-tugas mereka. Walaupun ada mereka menyelesaikan tugasnya, para siswa menyelesaikannya belum dengan sepenuh hati.

9. Kemampuan mengembangkan atau merinci suatu gagasan (kemampuan elaborasi). Kemampuan untuk mengembangkan atau merinci suatu gagasan belum penulis lihat pengembangannya dalam proses pembelajarn karena metode yang digunakan guru dalam mengajar tidak mengcover kemampuan ini, sehingga potensi siswa terupgrade dengan baik.

Dalam penelitian ini belum terlihat usaha guru Agama Islam dalam mengembangkan potensi siswanya. Indikasinya adalah siswa belum juga merasakan suasana belajar yang benar-benar menyenangkan seperti pembelajaran PAIKEM, akan tetapi sebaliknya siswa merasakan suasana pembelajaran yang loyo, penuh dengan ketidaksemangatan, akibatnya emosi siswa tidak berkembang dengan baik dan maksimal. Siswa-siswa belum mempunyai kemampuan untuk melakukan semua hal ini karena model pembelajaran yang tercipta dalam proses pembelajaran belum memberikan kesempatan untuk siswa untuk melakukannya, sehingga usaha untuk mengelola emosi terutama dalam meningkatkan kemampuan diri sendiri belum terealisasi denga baik.

\section{PENUTUP}

\section{Kesimpulan}

Usaha guru Pendidikan Agama Islam dalam mengembangkan potensi emosional siswa adalah: mengembangkan rasa ingin tahu yang besar; kemampuan mengajukan pertanyaan yang berbobot; kemampuan memberikan banyak gagasan dan usul terhadap suatu masalah; kemampuan menyatakan pendapat secara spontan dan tidak malumalu; kemampuan mempunyai pendapat sendiri dan dapat mengungkapkannya, tidak mudah terpengaruh orang lain; kemampuan mempunyai daya imajinasi yang kuat; kemampuan mengajukan pemikiran, gagasan pemecahan masalah yang berbeda dari orang lain (orisinil); kemampuan bekerja sendiri; kemampuan mengembangkan atau merinci suatu gagasan (kemampuan elaborasi). 


\section{Saran}

Kepada guru PAI di SMP N 29 Padang sebaiknya terus mengembangkan kemampuan diri untuk mencari cara-cara yang efektif, komprehensif dalam mengoptimalkan potensi siswa yang mampu menyentuh semua fungsi otaknya, hati, dan emosinya agar siswa-siswa mampu juga mengembangkan kemampuan dirinya sendiri sehingga terwujudnya insan kamil sesuai dengan nilai-nilai Islam. Selain itu diharapkan juga kepada guru PAI untuk memperkaya wawasannya dengan membaca buku-buku tentang potensi.

\section{KEPUSTAKAAN ACUAN}

Agustian, Ary Ginanjar, (2001). Rahasia

Sukses Membangun Potensi Emosi dan

Spiritual / ESQ, Jakarta: Arga Wijaya Persada.

-------, (2001). ESQ, Emotional, Spiritual Quotient, berdasarkan 6 rukun iman dan 5 rukun Islam Jakarta: Arga.

Arikunto, Suharsimi, (2001). Prosedur Penelitian Sebagai Suatu Pendekatan Praktek, Jakarta: Renika Cipta.
Departemen Agama Islam RI, Al-Qur'an dan terjemahannya, Bandung: PT. Syaamil Al-Qur'an

Hadi ,Sutrisno, (1987). Metodologi Research, Yogyakarta: Andi Offset.

Ishak W. Talibo, Artikel Membangun Potensi Emosional dalam Pandangan Pendidikan Islam, (ESQ Pdf.)

Mubayidh, Makmun, (2006). Potensi dan Kesehatan Emosional Anak, Jakarta: Pustaka Al-Kautsar.

Nawawi, Hadari, (1996). Penelitian Terapan, Yogyakarta: Gajah Mada Universitas Press.

Najati, Utsman, (1997). Alqur'an Dan Ilmu Jiwa, Bandung: Penerbit Pustaka. , (1993). Belajar EQ dan SQ dari Sunah Nabi, Jakarta: Penerbit Hikmah. --------, (2005). Psikologi dalam Alqur'an, Bandung: Pustaka Setia.

Nizar, Samsul, (2001). Pengantar Dasar Pemikiran Pendidikan Islam, Jakarta: Gaya Media Pratama.

Sahih Bukhari Jilid IV, Kuala lumpur, 2004. 